\title{
Fauna of Protected Areas and Dirology: A challenge for Youths
}

\section{Narayan Ramappa Birasal}

Zoology department, KLE Society's Gudleppa Hallikeri College, Haveri-581110, Karnataka, India

*Corresponding author: Narayan Ramappa Birasal, Zoology Department, KLE Society's Gudleppa Hallikeri College, Haveri-581110, Karnataka, India, Tel: 9449122732; E-mail: nrbirasal@gmail.com

Rec date: May 20, 2014; Acc date: May 21, 2014; Pub date: May 29, 2014

Copyright: () 2014 Birasal NR. This is an open-access article distributed under the terms of the Creative Commons Attribution License, which permits unrestricted use, distribution, and reproduction in any medium, provided the original author and source are credited.

\section{Introduction}

The Wildlife is one of the most gracious gifts of nature to this land, which is as rich in its variety and colours as its number. In order to conserve the existing wildlife of India, the Union and State governments and several Non-government organizations have given useful suggestions and made sincere efforts to declare the natural habitats as protected areas. This article provides information about protected areas and the available scope for the young researchers, environmentalists, budding ornithologists to publish their research work in reputed journals. As member of editorial board of Journal of Biodiversity \& Endangered Species, I hope that publication of details on fauna (non-domesticated animals) conserved in protected areas is useful for the future generation of researchers.

Wildlife can be found in all ecosystems. Wildlife is found in deserts, rain forests, plains, and other areas including the most developed urban sites [1]. Everybody hopes to build a future in which humans live in harmony with nature. The need for conservation of wildlife in India is often questioned because of the apparently incorrect priority in the face of direct poverty of the people. However, Article 48 of the Constitution of India specifies that, "The state shall endeavour to protect and improve the environment and to safeguard the forests and wildlife of the country" and Article 51-A states that "it shall be the duty of every citizen of India to protect and improve the natural environment including forests, lakes, rivers, and wildlife and to have compassion for living creatures." The majestic lion, the grateful yet fearsome tiger, unproductive leopard, powerful elephant, the nimble deer, attractive antelope, the picturesque peafowl, the gorgeous pelican, the beautiful parakeets, wood-pecker and the elegant flamingo are some of these of which any country might be proud.

\section{Indian National Resource}

There are 181 species of amphibians, 312 species of mammals, 399 species of reptiles, 1175 species of birds, and 60000 species of insects. Over the years, about 106 species of animals and about 140 species of birds have become extinct because of climate and geographic changes and also by over hunting by man for food, medicine, fur and many other reasons. According to ecologists, more than 600 species of animals and birds are expected to become extinct if not protected.

Human activities pose the biggest threat to wildlife because expanding human population results in expanding needs of man [2]. With scientific progress and technological development, man has started utilizing natural resources at a much larger scale. Continuous increase in population caused an increasing demand for resources. Wildlife is considered a renewable resource and hence its conservation is essential if we desire sustainable yields. Nature has endowed India with such abundant and varied fauna that it compares favorably with that of any country in the world whether it is developed, developing or underdeveloped.

India has large geographical size and variety of climate and habitats. Wild animals constitute great national resources. Preservation and protection of wildlife is important from the ecological point of view. The role of individual species in ecosystem (for example in food chain) cannot be undermined. Today amphibians are under a threat and their population has declined. This is the cause of ecological concern because some habitats and biomass of amphibians can exceed all other large animals combined.

\section{Management plans to conserve wildlife}

Wildlife, besides its crucial role in preventing ecological degradation has other values like serving as a genetic pool for livestock improvement. Management plans to conserve wild life are (i) The Indian Board of Wildlife was set up in 1952 to ensure protection and scientific management of the diminishing wildlife in the country (ii) Countrywide uniform legislation in the form of the Wild life (Protection) Act enacted in 1972 with object of ensuring stricter protection to wildlife and its better management (iii) The Forest (Conservation) Act passed in 1980, to impose a severe restriction, on the diversion of forestland to non-forest use. (iv) Establishment of (a) national parks, (b) wildlife sanctuaries, (c) biosphere reserves and (d) specials projects formulated for captive breeding and for rehabilitation of endangered species

Wildlife conservation is the practice of protecting endangered plant and animal species and their habitats. Among the goals of wildlife conservation are to ensure that nature will be around for future generations to enjoy and to recognize the importance of wildlife and wilderness lands to humans. Many nations have government agencies dedicated to wildlife conservation, which help to implement policies designed to protect wildlife. The science of extinction is called dirology. An endangered species is defined as a population of a living being that is at the danger of becoming extinct because of several reasons. Either they are few in number or are threatened by the varying environmental parameters.

Flagship species: like tiger, Indian bison or Gaur and Asian Elephant are found in sufficient numbers in India in some protected areas. A study carried out by Dr. Ullas Karanth of the Wildlife Conservation Society has contributed a lot in this field [3-5].

\section{Habitat destruction}

Some of the activities that are causing a destruction of habitat of flora and fauna are

Destruction of forest land for agriculture and other purposes: Large tracts of forest land have been cleaned up for monoculture plantations 
Page 2 of 6

like eucalyptus. This has led to the destruction of species that were dependent on the forest. This has adversely affected several species dependent on large tracts of scrub. The classic example is Great Indian Bustard [6].

Mining operations: clear out large areas of land and cause destruction to the species dependent on them. An example is the Kudremukh Iron Ore Company Limited which mined iron ore within the boundaries of the protected Kudremukh National Park [7].

\section{Human-wildlife conflict:}

Due to the loss of habitat, more and more species of fauna have started to venture into human habitation causing a conflict between humans and fauna. A typical species affected by this is the elephant which ventures out of the forest into human cultivations thereby eating or destroying the crops. In some cases, the elephants have also caused human deaths. In Karnataka state, between April and December 2012, a total of 157 elephants have died and about 18 people were killed in elephant attacks in the state. The figure is the highest ever since 2007-08. Majority of the elephants, about 141, died of natural causes, 3 due to gun shots and 13 of electrocution. The lack of food and water force elephants out of the forest and they end up in villages on the fringes of the forested areas [8].

\section{Pollution}

Release of industrial waste and human effluents into rivers have caused significant damages to species that reside in rivers and riverbanks. Air pollution is also a significant cause of concern in metros like Bangalore where it has been found that air pollution is discolouring foliage including those of ornamental plants. Pollution in rivers has caused sharp reduction in populations of animal species [9].

\section{Wildlife management}

With reference to wildlife, ecological subdivisions of India include (i) Himalayan mountain system (ii) Peninsular and (iii) Tropical rain forest region. Day by day, list of endangered and threatened animals is on rise. Due to continuous increase in the number of endangered species, steps have been taken to protect and manage the wildlife of the country. Government and Non-Government organizations like Bombay Natural History Society (BNHS), Wildlife Preservation Society (Dehradun), World Wildlife Fund, Indian Board of Wildlife etc have contributed a lot and dedicated to wildlife conservation.

\section{In-situ conservation of wildlife}

It is on-site conservation of genetic resources in natural populations of plant or animal species. It is the process of protecting an endangered plant or animal species in its natural home by protecting the habitat itself. Main benefit of in-situ conservation is that it maintains recovering populations in the surrounding where they have developed their distinctive properties. Another benefit is that this strategy helps ensure the ongoing processes of evolution and adaptation within their environments. Biodiversity conservation is mostly based on in situ conservation and this involves the protection of wildlife habitats. There are different categories of protected areas which are managed with different objectives for bringing benefits to the society. These include (A) National Parks (B) Sanctuaries (C) Biosphere Reserves (D) Nature / conservation reserves (E) Projects for endangered species

(A) National Parks: $\{$ IUCN category II Protected Areas\}: India's first national park was established in 1936 as Hailey National Park (now known as Jim Corbett National Park). India only had five national parks till 1970. In 1972, India enacted the Wildlife Protection Act to safeguard the habitats of conservation reliant species. Further legislation strengthening protections for wildlife was introduced in the 1980s. As a result, we have 104 national parks (till 2012). Total land covered in India under all National parks is $39,919 \mathrm{~km} 2$, comprising $1.21 \%$ of India's total surface area. Of the total 104 NPs, Karnataka state has five. Table 1 gives the salient features of National parks of Karnataka state.

\begin{tabular}{|c|c|c|c|c|}
\hline SI.No & $\begin{array}{l}\text { Name of the } \\
\text { National Park }\end{array}$ & $\begin{array}{l}\text { Located in the } \\
\text { district }\end{array}$ & $\begin{array}{l}\text { Spread over area } \\
\text { in } \mathrm{km}^{2} \text {. }\end{array}$ & Place common to see the following wildlife \\
\hline 1 & Anshi & Uttara Kannada & 250 & $\begin{array}{l}\text { Indian Elephant, Gaur, Wild boar, Sambar, Chital, Gray langur, Bonnet Macaque, Slender } \\
\text { Loris, Bengal Tiger, Jungle Cat, Indian Leopard, Leopard Cat, Small Indian Civet, Common } \\
\text { Mongoose, Golden Jackal, Sloth Bear, Malabar Giant Squirrel, Giant Flying Squirrel, Crested } \\
\text { Porcupine. King Cobra, Python, Great Hornbill, Malabar Pied Hornbill and Ceylon Frogmouth. }\end{array}$ \\
\hline 2 & $\begin{array}{l}\text { Bandipur (First } \\
\text { Tiger reserve of } \\
\text { India) }\end{array}$ & Chamarajnagar & 800 & $\begin{array}{l}\text { Gaur, Sambar, Spotted deer, Barking deer, Mouse deer, Bonnet macaque, Slender loris, Red } \\
\text { Giant Flying Squirrel, Bengal Tiger, Leopard, Common Palm Civet, Small Indian Civet, Sloth } \\
\text { Bear, Asiatic Wild Dog, Striped Hyena, Golden Jackal, Trinket Snake }\end{array}$ \\
\hline 3 & Bannerughatta & Bangalore & 115 & $\begin{array}{l}\text { Indian Leopard, Gaur, Indian Elephant, Golden Jackal, Fox, Wild boar, Sloth Bear, Sambar, } \\
\text { Spotted deer, Barking deer, Common Langur, Bonnet Macaque, Indian Crested Porcupine }\end{array}$ \\
\hline 4 & Kudremukh & $\begin{array}{l}\text { Encompasses } \\
\text { regions in the } \\
\text { districts of Dakshina } \\
\text { Kannada, Udupi an } \\
\text { d Chikmagalur }\end{array}$ & 600 & $\begin{array}{l}\text { Bengal Tiger, Indian Leopard, Golden Jackal, Lion-tailed Macaque, Common Langur, Sloth } \\
\text { Bear, Gaur, Sambar, Spotted deer, Barking deer, Malabar Giant Squirrel, Indian Giant Flying } \\
\text { Squirrel, Indian Crested Porcupine, Malabar Trogon, Great Hornbill, Malabar Whistling } \\
\text { Thrush, Imperial Pigeon. }\end{array}$ \\
\hline 5 & $\begin{array}{l}\text { Nagarhole (Rajiv } \\
\text { Gandhi) }\end{array}$ & $\begin{array}{l}\text { Situated in districts } \\
\text { of Mysore and } \\
\text { Kodagu }\end{array}$ & 575 & $\begin{array}{l}\text { Gaur Sambar, Spotted deer, Barking deer, Mouse deer, Four horned Antelope, Giant fruit bat, } \\
\text { Rusty spotted Cat, Common palm civet, Sloth bear, Asiatic wild dog, Falcons, Partridges, } \\
\text { Quails, Peafowl, Owls. }\end{array}$ \\
\hline
\end{tabular}

Table 1: Important National Parks of Karnataka state 
Page 3 of 6

(B) Wildlife Sanctuaries: $\{$ IUCN Category IV Protected Areas $\}$ : India has more than 500 wildlife sanctuaries. Many National Parks were declared initially as wildlife sanctuaries. These protected areas are of national importance to conservation, usually due to some flagship faunal species. Example: National Chambal Wildlife Sanctuary for conserving the gharial. Table 2 gives the salient features of Wildlife sanctuaries of Karnataka state and Table 3 gives details of protected areas for bird's heronry in Karnataka state.

\begin{tabular}{|c|c|c|c|c|}
\hline & Name of the Bird sanctuary & Located in the district & $\begin{array}{l}\text { Spread over } \\
\text { area in } \mathrm{km}^{2}\end{array}$ & Place common to see the following wildlife \\
\hline 1 & Adichunchanagiri & Mandya & 0.88 & Created mainly for the conservation of peacocks \\
\hline 2 & Arabithittu & Mysore & 13.5 & Leopard, Fox and Spotted deer \\
\hline 3 & Biligiriranga Swamy Temple & Chamarajnagar & 539.58 & $\begin{array}{l}\text { Sloth bear, Gaur, Sambar, Nilgiri wood pigeon, Malabar whistling thrush, } \\
\text { Yellow-throated bulbul, Peregrine falcon, Rufousbellied hawk eagle,. } \\
\text { Endangered amphibian, Icthyophis ghytinosus' }\end{array}$ \\
\hline 4 & Bhadra & Chikkamagalur \& Shimoga & 492.46 & $\begin{array}{l}\text { Tiger, Leopard, Elephant, Gaur, Slender loris, Pangolin, Ruby throated } \\
\text { bulbul, Shama, Malabar whistling thrush }\end{array}$ \\
\hline 5 & Brahmagiri & Kodagu & 181.8 & Elephant, Gaur, Tiger, Jungle cat, Bbonnet macaque \\
\hline 6 & Cauvery & $\begin{array}{l}\text { Bangalore, Mysore \& } \\
\text { Mandya }\end{array}$ & 102.59 & $\begin{array}{l}\text { Leopard, Elephant, Sambar, Common otter, Endangered grizzled giant } \\
\text { squirrel. Sanctuary is famous for Mahseer fish (Tor sp.) }\end{array}$ \\
\hline 7 & Dandeli & Uttara Kannada & 475.02 & Gaur, Wild pig, Slender loris, Malabar giant squirrel, Barking deer \\
\hline 8 & Daroji (Sloth Bear Sanctuary) & Bellary & 55.87 & This sanctuary was mainly created for the preservation of Sloth bears. \\
\hline 9 & Melukote temple & Mandya & 45.82 & Wolf, Leopard, Blackbuck, Pangolin. \\
\hline 10 & Mookambika & Udupi & 247 & $\begin{array}{l}\text { Slender loris, Lion-tailed macaque, Sambar, Chital and endangered Cane } \\
\text { turtle }\end{array}$ \\
\hline 11 & Nugu & Mysore & 30.32 & Elephant, Gaur, Leopard, Spotted deer and Common palm civet. \\
\hline 12 & Pushpagiri & Kodagu & 102.59 & $\begin{array}{l}\text { Elephant, Tiger, Slender loris, Bonnet macaque, Great pied hornbill, } \\
\text { Malabar trogon, Nilgiri blackbird. }\end{array}$ \\
\hline 13 & Ranebennur & Haveri & 119 & $\begin{array}{l}\text { This sanctuary was created mainly for the conservation of blackbucks. } \\
\text { This sanctuary is also a habitat for the endangered Great Indian Bustard. }\end{array}$ \\
\hline 14 & Sharavathi Valley & Shimoga & 431.23 & $\begin{array}{l}\text { Tiger, Leopard, Mouse deer, Bonnet macaque, Common langur, Paradise } \\
\text { flycatcher, Racket-tailed drongo, Bluethroated barbet }\end{array}$ \\
\hline 15 & Shettihalli & Shimoga & 395.6 & Tiger, Leopard, Bonnet macaque, Malabar giant squirrel \\
\hline 16 & Someshwara & Udupi & 88.40 & Tiger, Leopard, Lion-tailed macaque, Spotted deer \\
\hline 17 & TalaCauvery & Kodagu & 105 & $\begin{array}{l}\text { Clawless otter, Elephant, Tiger, Striped necked mongoose, Mouse deer, } \\
\text { Fairy bluebird, Malabar trogon, Broadbiller roller }\end{array}$ \\
\hline
\end{tabular}

Table 2: Important Wildlife sanctuaries of Karnataka state

(c) Biosphere Reserves: \{category roughly corresponding to IUCN Category V Protected Areas\}. The Indian government has established 18 Biosphere Reserves, which protect larger areas of natural habitat than a National Park or wildlife Sanctuary, and often include one or more National Parks and or preserves, along buffer zones that are open to some economic uses. Protection is granted not only to the flora and fauna of the protected region, but also to the human communities who inhabit these regions. Table 4 gives the gives details of Biosphere reserves of India.

\begin{tabular}{|l|l|l|l|l|}
\hline & Name of the Bird sanctuary & $\begin{array}{l}\text { Located in the } \\
\text { district }\end{array}$ & Spread over area in $\mathrm{km}^{2}$. & Place common to see the following birds \\
\hline 1 & Attiveri & Uttara Kannada & 2.23 & $\begin{array}{l}\text { White ibis, little cormorant, pied kingfisher, } \\
\text { common grey hornbill, Paradise fly catcher }\end{array}$ \\
\hline 2 & Gudavi & Shimoga & 0.73 & $\begin{array}{l}\text { White ibis, Pheasant-tailed jacana, Purple } \\
\text { moorhen, Little grebe }\end{array}$ \\
\hline
\end{tabular}




\begin{tabular}{|l|l|l|l|l|}
\hline 3 & Ranganathittu & Mandya & 0.67 & $\begin{array}{l}\text { Cormorants, Darter, Great stone plover, Cliff } \\
\text { swallow, Spoonbills, Lesser whistling teal } \\
\text { (Roosting site for some birds) }\end{array}$ \\
\hline 4 & Mandagadde & Shimoga & Small island on Tunga river & Median Egret, Little Cormonant, Darter \\
\hline 5 & Kaggaladu Heronry & Tumkur & $\begin{array}{l}\text { Known as best heronry for painted storks in } \\
\text { South India }\end{array}$ & $\begin{array}{l}\text { Birds found nesting here are painted storks, } \\
\text { grey herons, pelicans, black stilts and ducks. }\end{array}$ \\
\hline 6 & Kokkare Bellur & Mandya & $\begin{array}{l}\text { Haven for avian species like Spot Billed } \\
\text { Pelican \& Painted Storks }\end{array}$ & $\begin{array}{l}\text { Apart from pelicans and storks, 250 species of } \\
\text { birds have been sighted here }\end{array}$ \\
\hline 7 & Magadi & Gadag & 0.54 & Bar-headed geese \\
\hline 8 & Ghataprabha & Belgaum & 29.78 & $\begin{array}{l}\text { Demoiselle Crane, European White Stork, } \\
\text { River terns }\end{array}$ \\
\hline 9 & Bankapur Peacock Sanctuary & Haveri & 0.56 & $\begin{array}{l}\text { This sanctuary was created mainly for the } \\
\text { conservation of Peacocks. (Declared on June } \\
9,2006)\end{array}$ \\
\hline 10 & Bonal & Yadgir & $\begin{array}{l}\text { After Ranganthittu Bird Sanctuary, Second } \\
\text { largest bird sanctuary in the state. }\end{array}$ & $\begin{array}{l}\text { Purple heron, White-necked stork, Black ibis, } \\
\text { Brahminy duck }\end{array}$ \\
\hline
\end{tabular}

Table 3: Important Bird heronries of Karnataka state

(D) Nature/conservation reserves: A landmark decision taken for conserving biodiversity rich rivers and basins is the declaration of three conservation reserves in Uttar Kannada district of Karnataka, namely (i) 299.52 Sq.Km area as Aghanshini Lion Tailed Macaque Conservation Reserve (ii) 57.07 Sq. Km area as Bedthi Conservation Reserve, and (iii) 52.5 Sq.Km area as Hornbill Conservation Reserve, on May 31, 2011 by Karnataka state Government. Recently, Bedthi, Aghanashini and Kali river valleys in Uttara Kannada district received Conservation Reserve tag. The three reserves are set out to protect Lion Tailed Macaque Habitats, rare and endangered Myristica Swamps of the Western Ghats and Hornbill habitats [10]. The focus is conserving each of these iconic species, the end result of protecting the entire ecosystem will lead to conservation of a number of other endemic and endangered species including the free flowing rivers. It is hoped that these conservation reserves herald a beginning of innovative ways devised by experts to protect our valuable free flowing rivers. Many such rivers all across the country have been nurturing biodiversity and supporting livelihoods and it is high time that civil society groups, scientists and policy makers come together and look for various ways to protect these rivers from the onslaught of dams and pollution, for the current and future generations (Figure 1).

\begin{tabular}{|l|l|l|l|l|l|l|}
\hline & Year & Name & Location & State & Type & $\begin{array}{l}\text { Area } \\
\text { Kilometer) }\end{array}$ \\
\hline 1 & 1986 & Nilgiri Biosphere Reserve & $\begin{array}{l}\text { Part of Waynad, Nagarhole, Bandipur and } \\
\text { Mudumalai, Nilambur, Silent Valley and } \\
\text { Anaimalai Hills }\end{array}$ & $\begin{array}{l}\text { Tamil Nadu, Kerala and } \\
\text { Karnataka }\end{array}$ & Western Ghats & 5520 \\
\hline 2 & 1988 & Nanda Devi & $\begin{array}{l}\text { Parts of Chamoli dt, Pithoragarh dt } \\
\text { \& Bageshwar District }\end{array}$ & Uttarakhand & $\begin{array}{l}\text { Western } \\
\text { Himalayas }\end{array}$ & 5860 \\
\hline 3 & 1988 & Nokrek & Part of Garo Hills East Himalayas & 820 \\
\hline 4 & 1989 & Gulf of Mannar & $\begin{array}{l}\text { Indian part of Gulf of Mannar extending from } \\
\text { Rameswaram island in the North to } \\
\text { Kanyakumari in the South of Tamil Nadu and Sri } \\
\text { Lanka } \quad \text { Tamil Nadu }\end{array}$ & Coasts \\
\hline 5 & 1989 & Manas & $\begin{array}{l}\text { Part of Kokrajhar, Bongaigaon, Barpeta, } \\
\text { Nalbari, Kamrup \& Darrang Districts }\end{array}$ & Assam & East Himalayas & 2837 \\
\hline 6 & 1989 & Sundarbans & $\begin{array}{l}\text { Part of delta of Ganges and Barahamaputra river } \\
\text { system }\end{array}$ & West Bengal & Gangetic Delta & 9630 \\
\hline 7 & 1989 & $\begin{array}{l}\text { Great Nicobar Biosphere } \\
\text { Reserve }\end{array}$ & $\begin{array}{l}\text { Southern most islands of Andaman and Nicobar } \\
\text { Islands }\end{array}$ & $\begin{array}{l}\text { Andaman and Nicobar } \\
\text { Islands }\end{array}$ & Islands \\
\hline 8 & 1994 & Simlipal & Part of Mayurbhanj district & Odiksha & Deccan Peninsula & 4374 \\
\hline 9 & 1997 & Dibru-Saikhowa & Part of Dibrugarh and Tinsukia districts & Assam & East Himalayas & 765 \\
\hline
\end{tabular}


Page 5 of 6

\begin{tabular}{|l|l|l|l|l|l|l|}
\hline 10 & 1998 & Dihang-Dibang & Part of Siang and Dibang Valley & Arunachal Pradesh & Eastern Himalaya & 5112 \\
\hline 11 & 1999 & Pachmarhi & $\begin{array}{l}\text { Parts of Betul, Hoshangabad \& Chhindwara } \\
\text { Districts }\end{array}$ & Madhya Pradesh & Semi-Arid & 4982 \\
\hline 12 & 2000 & Khangchendzonga & Parts of Kanchanjunga Hills & Sikkim & East Himalayas & 2620 \\
\hline 13 & 2001 & $\begin{array}{l}\text { Agasthyamalai Biosphere } \\
\text { Reserve }\end{array}$ & $\begin{array}{l}\text { Neyyar, Peppara \& Shenduruny Wildlife } \\
\text { Sanctuary and their adjoining areas }\end{array}$ & Kerala, Tamil Nadu & Western ghats & 1828 \\
\hline 14 & 2005 & $\begin{array}{l}\text { Achanakamar } \\
\text { Amarkantak }\end{array}$ & Parts of Annupur, Dindori and Bilaspurdi districts & $\begin{array}{l}\text { Madhya Pradesh, } \\
\text { Chhattisgarh }\end{array}$ & Maikala Hills & 3835 \\
\hline 15 & 2008 & Great Rann of Kutch & $\begin{array}{l}\text { Part of Kutch, Rajkot, Surendranagar \& Patan } \\
\text { districts }\end{array}$ & Gujarat & Desert \\
\hline 16 & 2009 & Cold Desert & $\begin{array}{l}\text { Pin Valley National Park and surroundings; } \\
\text { Chandratal and Sarchu \& Kibber Wildlife } \\
\text { Sancturary }\end{array}$ & Himachal Pradesh & $\begin{array}{l}\text { Western } \\
\text { Himalayas }\end{array}$ & 7770 \\
\hline 17 & 2010 & Seshachalam Hills & $\begin{array}{l}\text { Seshachalam Hill Ranges covering parts of } \\
\text { Chittoor and Kadapa districts }\end{array}$ & Andhra Pradesh & Eastern Ghats & 4755 \\
\hline 18 & 2011 & Panna & $\begin{array}{l}\text { Part of Panna and Chattarpur Districts } \\
\text { Madhya Pradesh }\end{array}$ & $\begin{array}{l}\text { Catchment area } \\
\text { of the Ken River }\end{array}$ & 543 \\
\hline
\end{tabular}

Table 4: Important Biosphere Reserves of India

(E) Projects for endangered species: For conservation of wildlife, the threatened species have been classified as endangered, vulnerable and rare according to the degree of danger they face for survival. Following are some of the special projects launched to protect selected wildlife (i) Hangul project: was started in 1970 to protect Hangul (Kashmir Stag). (ii) Gir Lion Project: was started in 1973. The Gir forest in Saurashtra peninsula of Gujarat state is the only surviving habitat of the Asiatic Lion (Panthera leon persica). (iii) Project Tiger: was started in 1973. There are 25 tiger reserves in India covering 30,000 sq.km area. (iv) Crocodile Breeding project: The project came into existence with a proposal from Dr H R Bustard, an FAO expert on crocodile breeding and management, for the development of a crocodile farming industry in India. The project was initiated in 1975. There are 3 species of crocodiles in India (a) saltwater or estuarine crocodile (Crocodylus porosus), (b) Freshwater (swamp) crocodile (C. palustris) and (c) Gharial (Gavialis gangeticus). Gharial eggs were hatched for the first time in captivity anywhere in the world at Yikerpada, (Dgenkanal district, Orissa). 16 crocodile rearing centres have been developed in India. (v) Brow antlered-deer project: was started in 1977 in Manipur to protect Brow antlered-deer (vi) Rhino conservation project: It was introduced in 1987 in Assam and is continued for effective and intensive management of rhino habitats. Dudhwa National Park was selected for this project. (vii) Snow leopard project: It was taken up to create 12 snow-leopard reserves throughout Himalayas (viii) Project elephant: was started in 1992 with the aim at ensuring long term survival of identified viable populations of elephants (ix) Yak project research centre : was started at West Kameng, Arunachal Pradesh.

\section{Exclusive areas}

As special effort, both the Union and State governments have declared habitats to conserve the exclusive species in particular areas. A few examples of such declared areas in Karnataka state are (A) Ranebennur Blackbuck sanctuary $\left(119 \mathrm{~km}^{2}\right)$ was declared as wildlife sanctuary in June 1974 to protect Blackbucks (B) Daroji Sloth Bear Sanctuary in Bellary district in Karnataka [11]. The sanctuary was exclusively created for the preservation of Indian Sloth bears in

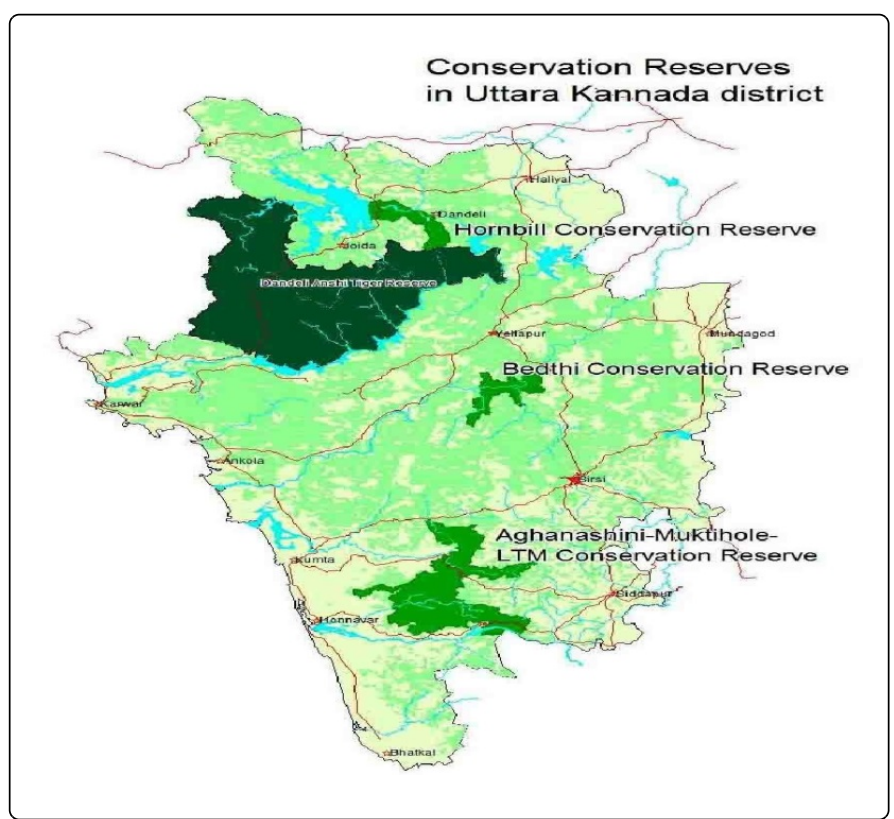

Figure 1: Map showing Conservation reserves in Uttara Kannada district

October 1994. (C) Bankapur peacock sanctuary in Haveri district was established in June 2006. Understanding the great presence of peacocks in 139 acres of Bankapur fort area, the government took decision to preserve the natural habitat of Indian national bird [12]. (D) Butterfly Park: first of its kind was established in November 2006 [13]. The Butterfly Park is spread across 7.5 acres of land. The butterfly conservatory (a circular enclosure with a poly-carbonate roof of $10,000 \mathrm{sq} \mathrm{ft}$ provide the living environment to support more than twenty species of butterflies). The environment has a tropical 
Citation: Birasal NR (2014) Fauna of Protected Areas and Dirology: A challenge for Youths. J Biodivers Endanger Species 2: e115. doi:

Page 6 of 6

setting, with a humid climate, an artificial waterfall, and appropriate flora to attract butterflies.

\section{Conclusion}

Among the goals of wildlife conservation are to ensure that nature will be around for future generations to enjoy and to recognize the importance of wildlife and wilderness lands to humans. Many nations have government agencies dedicated to wildlife conservation. Numerous independent nonprofit organizations also promote various wildlife conservation causes. Wildlife conservation has become an increasingly important practice due to the negative effects of human activity on wildlife. In spite of all efforts, more forest area is needed for greater interest of protecting wildlife from the adverse effect of climate change. Optimum afforestation could help stop degradation of environment and biodiversity, making the country a safe habitat for all. It is the time to formulate a time-befitting policy, that the present impacts of climate change had adversely affected the region's agriculture, ecology, bio-diversity, weather, environment etc. Hence it is for the youths to take up this challenge to conserve the fauna of protected areas and prevent science of extinction of wildlife i.e dirology.

\section{References}

1. Sharma PD (1993) Environmental Biology. Rastogi and company, Meerut, India.

2. Hosetti BB, Venkateshwarlu (2001) Trends in wildlife biodiversity conservation and management. Volume 1 \& 2. Daya Publishing House, Delhi: 320-347.
3. Ullas Karanth K (1995) Estimating tiger Panthera tigris populations from camera-trap data using capture-recapture models. Biology conservation 71: 333-338.

4. Ullas Karanth K, Nichols D James (1998) Estimation of tiger densities in India using photographic captures and recaptures. Ecology 79: 2852-2862.

5. Treves A, Ullas Karanth K (2003) Human carnivore conflict and perspectives on carnivore management worldwide. Conservation Biology 17: 1491-1499.

6. Sutirtha Dutta, Asad R Rahmani and Yadvendradev V Jhala (2013) Running out time? The great Indian Bustard Ardeotis nigriceps - Status, viability and conservation strategies. European Journal of Wildlife Research 57: 615-625.

7. Krishnaswamy J, Bunyan M, Mehta VK, Jain N, Karanth KU (2006) Impact of iron ore mining on suspended sediment response in a tropical catchment in Kudremukh, Western Ghats, India. Forest Ecology and Management 224: 187-198.

8. Milton L (2013) Karnataka witnesses highest elephant deaths. The Times of India February 6, 2013.

9. Madhav Gadgil (2004) Karnataka State of Environment Report and Action Plan Biodiversity Sector. 301.31 P04 (CES) ENVIS Technical Report No. 16: 117.

10. Kanagavel A , Pandya R, Sinclair S, Prithvi A, Raghavan R (2013) Community and conservation reserves in southern India: status, challenges and opportunities. Journal of Threatened Taxa 5: 5256-5265.

11. Harisha MN, Hosetti BB (2013) An assessment of floristic diversity of Daroji Sloth Bear Sanctuary, Hospet, Bellary district, Karnataka, India. Journal of Research in Biology 3: 828-839.

12. Birasal NR (2007) Bankapur fort: The first peacock reserve of Karnataka. March of Karnataka 45: 13-16.

13. Anon (2006) Butterfly Park to be inaugurated today. The Hindu, November 25, 2006 